\title{
The Archaeoseismology of Historical Buildings: A Model Study from the L'Aquila Area in Italy
}

\author{
Alessio Marchetti ${ }^{1}$, Fabio Redi ${ }^{2}$, Francesca Savini ${ }^{2}$ and Ilaria Trizio ${ }^{1}$ \\ 1. ITC-CNR, Institute for Construction Technologies, Italian National Research Council, L'Aquila 67100, Italy; \\ 2. DSU-Univaq, Department of Human Studies, University of L'Aquila, L'Aquila 67100, Italy
}

\begin{abstract}
Much of Italy is characterised by two features: an increased risk of seismic activity and a profusion of old and historic buildings. These factors force us to consider the relationship between building safety and practices of conservation and protection, and as such have a direct bearing on our approach to preserving the country's cultural heritage in general. The guidelines issued on the assessment and reduction of seismic risk to cultural heritage assets in the Prime Ministerial Decree (DPCM) of 9 February 2011 underline the importance of studying such properties in terms of their vulnerability to seismic activity, using "factors of confidence" (FC) to translate the qualitative assessments produced during previous phases into quantitative measurements. In addition to the building survey, which describes the precise three-dimensional form of a structure and the relationships between its constituent parts, a substantial part of our knowledge of a building is provided by stratigraphic analysis of the above-ground elements. Similarly, a great deal of useful information can be derived from historical analysis. This paper outlines an archaeoseismological study developed by archaeologists from the University of L'Aquila and researchers from the ITC-CNR in the same city, which applies a multi-disciplinary approach to the study of historic buildings in areas of seismic activity.
\end{abstract}

Key words: Archaeoseismology, cultural heritage, knowledge, conservation, assessment.

\section{Introduction}

The "Guidelines for Evaluating and Reducing Seismic Risk to Cultural Heritage Assets" issued by the Italian Ministry of Cultural Assets and Activities ("Ministero dei beni e delle attività culturali" or "MiBAC") [1], which seek to standardise approaches to the conservation of cultural assets in areas prone to seismic activity, are the fruit of a synergistic process of interaction between scientific and humanistic areas of study. The concept of archaeoseismology, however, has only really come to the fore in recent decades [2-6]. Today, we can point to many cases in which this new approach has been applied, both within Italy, most recently in the Abruzzo and Emilia regions, and internationally; consider, for instance, the numerous archaeoseismological studies conducted in Greece,

Corresponding author: Ilaria Trizio, researcher; research fields: procedure for archaeological, architectural and urban survey; use of the ICT applied to the analysis of the built heritage (3D GIS and HBIM). E-mail: ilaria.trizio@itc.cnr.it.
Turkey and Crete, and in many Eastern and Middle Eastern countries [7-10].

Such examples clearly demonstrate how the collection of evidence of seismic activity-by calculating the possible material effects of one or more earthquakes - when combined with archaeological investigation of the immediate setting, can yield vital information that might otherwise have been entirely unavailable.

The potential of archaeological data in the field of architecture has only begun to be addressed very recently, relatively speaking [2, 5, 6, 9-18], with a constant and growing focus on the sector of seismic risk prevention [2, 14, 19-25]. As such, we find that from purely historical research, in which seismic data, if available, was considered useful for the purposes of dating or interpreting specific research contexts, we have passed to theoretical and practical studies that examine buildings with a view to understanding their construction and seismic history [12-14, 19, 21, 24-27]. 
An archaeoseismological approach requires the collaboration of various professional figures, both as a result of the methods it involves, and due to the broad range of applications it enjoys in a variety of fields. This is not surprising, particularly if we appreciate that documenting and recording data on our cultural heritage forms the basis for conservational, archaeological and art-historical research projects and efforts to safeguard our cultural assets, such as seismic-risk prevention and monitoring the condition of complex architectural structures with a view not only to ensuring their conservation, but also making them accessible to, and usable by, the wider population.

This methodology has identified, in the fields involved in the reconstruction process following the 2009 earthquake, the basis for an active form of collaboration between different bodies, and a synergistic meeting of different professional figures (archaeologists, architects, engineering, geologists, etc.), one that will assist us in identifying methodological approaches to meet the demands of caring for, recovering, re-employing and restoring our cultural heritage assets.

To test this methodology, the Castle of Fossa - in the village of the same name a few miles from L'Aquila, in the so-called "seismic crater" - was selected from the many examples of "cultural heritage asset" present in the area.

\section{The Research Project: Context and Motivation}

To learn about a cultural asset, to promote it, and to derive the greatest value from it: it is in terms of these three intentions that we measure any common attempt we may make to recover the past of such a property and root it fully within the present to ensure that it is actively preserved going forward.

We learn about the historic, artistic and archaeological context of a site not only by reading the layers of the earth, stratigraphically, but also by examining the palimpsest of historical building work that has been carried out on it over time. We promote it by sharing this knowledge through a combination of modern and traditional instruments of communication and advanced technologies. We derive the greatest value from the site, ultimately, by identifying its diachronic qualities and peculiarities-its history-through reconstructions and processes of restoration that reflect the particular technical, formal and compositional features of each historical period, and especially by restoring functionality in a manner that is compatible with the past but that also fulfils the needs of the present and the future. As such, the process of reconstruction that follows an earthquake, or any other form of natural or anthropogenic hazard or emergency, must inevitably reflect these three considerations: learning about, promoting, and deriving the greatest value from the property in question. Over time, this has informed the development of a methodology that can be used in any geographic context, and that we attempt, here, to describe.

Along with the municipality of L'Aquila, the area affected by the 2009 earthquake - the so-called "seismic crater"-includes 56 "minor" municipalities across an area of hills and mountains in the central Apennines. It is a region of outstanding nature and scenic beauty that includes a number of protected areas (the Gran Sasso and Monti della Laga national park, the Sirente-Velino regional park, and various nature reserves) and a diverse range of human settlements, with areas of limited human impact, such as those in the high mountains, and areas of greater human presence, such as the river valleys, basins and upland plains located between the mountains proper.

This heterogeneity itself lends the region a number of distinctive qualities. Here, the bond between the inhabitants and their environment has persisted, virtually unchanged, for millennia, driven by the use of natural resources, sheep-farming and the cultivation of crops. The immeasurable scenic and natural 
patrimony created by the region's geomorphological complexity and the variety of its ecosystems and plant and animal life in general, is enhanced by the numerous markers that this harmonious coexistence has left over the centuries. If we describe the historic towns and villages of the crater as "minor", it is purely in reference to their size - in terms of both physical extension and population - and not, by any means, to their historical and cultural worth, which is expressed at a number of different scales, from that of individual buildings to the broader urban context and wider landscape. Indeed, throughout the region, we find examples of remarkable buildings framed by historic urban landscapes of comparable overall architectural quality, which are themselves integrated organically with surrounding landscapes of immeasurable scenic and environmental richness.

In addition to the traditional imperative of historical accuracy and consistency, in these towns and villages we have to contend with a rich fabric of buildings, structures and urban landscapes that paint a varied and differentiated diachronic picture of different ages in the history of the region. The 57 municipalities of the "crater" fall variously within the provinces of L'Aquila (42), Teramo (8) and Pescara (7), while in terms of geographical, historical and cultural cohesion, they can be grouped into at least 10 different territorial units.

Ultimately, whatever material we are able to uncover - whether physical or intangible - will serve alongside the highland landscapes, ancient drove roads, dry stone constructions, traditional water networks and water mills in providing the basis for an organic, integrated approach to the recovery of an ancient, multi-layered patrimony of immeasurable value, an approach that will instrumental in promoting development thanks to the three criteria outlined above: "learning about", "promoting", and "deriving the greatest value from".

Starting in the early twentieth century, the area in question has been marked by a sharp fall-off in population, as a result of which a large number of buildings are underused, or not used at all. Consequently, many buildings in the region are inadequately maintained, which leaves them particularly vulnerable. Emigration has also seen the partial abandonment of traditional agricultural practices, which has repercussions in terms of land maintenance and changes to the landscape. At the same time, however, the depopulation of these minor towns and villages - a result of the shifting economic and employment landscape of the previous century-has meant that a large proportion of their traditional architecture has remained intact and escaped the "modernisation" that might otherwise have compromised its historic character. In a sense, the history of the area has allowed it to retain, in the centres of these minor towns and villages, a legacy of buildings that, in terms of methods and materials of construction, are characteristic of the places and periods in which they were built, that have a distinct and pronounced character in their own right, and that are integrated harmoniously with the surrounding landscape.

The most recent earthquake damaged a large portion of the region's historic architecture, aggravating - seriously in many cases - the already perilous conditions of many buildings. The reconstruction process, however, offers an opportunity to focus our efforts on recovering, and making better use of, this patrimony. Indeed, we believe it can even serve as the springboard for a long-awaited process of socio-economic regeneration.

\section{Case Study in the Context of Reconstruction}

The Municipality of Fossa's reconstruction programme ("Piano di Ricostruzione" or "PdR") was drafted by the universities of Catania (Prof. C. Carocci) and Genoa (Prof. S. Lagomarsino), was approved by the authorities in 2013, and was adopted by the municipal council the same year. The programme 
coordinates the municipality's various post-earthquake reconstruction initiatives. It identifies a number of "nuclei of urban regeneration" within the designated perimeter, which includes the village centre. One of these nuclei is the area of the Castle_-"RU_A", or "nucleo di Riqualificazione Urbana del borgo fortificato"-which includes the various groups of castle buildings (separated into two consortia) and the private properties that lie inside the walls uphill from the castle proper.

The PdR's technical implementation standards ("Norme Tecniche di Attuazione" or "NTA") require not only that public spaces be restored but that they also be made compliant with recent legislation, which entails improved accessibility, additional public facilities and better private and public car-parking provision. They also outline the requirements for the restoration of existing buildings within the nuclei, a process that may include changes to the designated use of a site. In the case of the Castle, it permits changes designed to restore the building to use and increase its usefulness to the wider public.

The buildings in the Castle nucleus have been earmarked for stabilisation and a process of conservation and restoration that will aim to preserve their general structural and typological character in addition to more specific architectural elements and decorations.

In June 2013, following the completion of a general study of the castle, a "Request for the recognition of the cultural importance of the buildings of the Castle of Fossa" was submitted to the Abruzzo region's Authority for Building Conservation. This was the beginning of the process of securing official recognition of the unique historical, artistic and architectural value of the building we describe here as the "Castle". This process culminated in December 2013 when the Abruzzo's Regional Authority for Architectural and Scenic Assets issued planning restrictions that recognised the site's elevated artistic and architectural value. These restrictions cover all of the old fortified "borgo", which is to say all of the buildings and land enclosed by the castle walls. As such it implies that the whole fortified structure is intended to be considered as a single unit.

With the exception of the circular tower, which was subject to restoration work in the 1980s, the Castle buildings are private properties that had been in constant use as residences up until the earthquake of 2009.

Against this backdrop, we note a varying state of conservation between the southern fortifications, which adjoined the occupied buildings, and their northern counterparts, which were unused and had fallen into a state of neglect. Generally, in spite of issues linked to soil erosion, regulations and the general post-earthquake reconstruction timetable, the private residents and owners have expressed an amenableness to making their property available, in part, for such purposes as are conducive to greater public utility, in terms of the conservation and better use of the Castle as a whole.

\section{Archeoseismological Survey of the Castle of Fossa}

Against the wider drive to "learn about", "promote" and "derive the greatest value from" the area's cultural heritage assets, Fossa and its surroundings have been identified as the setting for a first, sample investigation whereby a range of requirements and objectives within the context of the area's post-earthquake regeneration are addressed together and treated synergistically as part of a more effective, consensus-driven approach to the process of reconstruction itself.

In addition to traditional concerns with historical accuracy and consistency, the study has to contend with a research context that presents a varied array of considerations with implications in a number of fields. In physical terms, however, it is suitably limited in size, being bordered by Fossa itself, to the north, Stiffe to the south, the slopes of Mount Ocre to the west and Mount Cerro to the east. This area of the basin of the River 
Aterno was once under the dominion of the Vestini-Roman city of Aveia, and subsequently that of the Lombard gastaldate of Forcona. Thereafter, it was subject to the various processes of population and fortification carried out by the Normans, Swabians, Angevins and, ultimately, the Aragonese. With an eye on this varied history (and the related issue of historical consistency), we find that the area evinces a rich fabric of buildings, structures and urban landscapes that paint a multiplicious and differentiated diachronic picture of region's past.

The project proposes to combine the complexities and demands of the process of post-earthquake reconstruction with a number of aspects more commonly associated with building protection, and specifically with the use of preliminary investigations to facilitate the recovery, re-use and regeneration of the aforementioned "minor" towns and villages and their surrounding territories.

Carrying out preliminary investigations in such densely stratified sites effectively involves a cross-disciplinary approach designed to provide a full and accurate reading of the property and the history of the various iterations of building work carried out on it over time. Marrying these considerations with those of a technical or regulatory nature, and the ultimate aims of the reconstruction project, requires a range of skill sets and professional profiles, or rather a range of professional figures who must be prepared to work together, compare notes and trace the relationships between their respective disciplines. In this way, it is possible to facilitate a better, more effective planning process and improve management of the work and procedures themselves, even after the work has started, thus reducing the risk of disputes and delays. With this approach, the restoration project cannot be fully configured on the basis of procedural and normative specifications alone. Rather, it has to be conceived as a single, unitary project in which a number of different fields of research and documentation are brought together, and through which these areas of knowledge can contribute to the better and more universal use of the property in question and form the basis of an active process of preservation and effective stewardship of historical assets and their surrounding areas.

As such, it is with a view to forming a better idea of issues that may arise in the implementation of the PdR that we have pursued the archeoseismological research project described in these pages. The data provided will be used not only in evaluating the potential vulnerability of historic buildings, but will also serve to provide a better understanding of their seismic history and local geographical context.

At the Castle of Fossa, the research team-which comprises engineers, structural engineers, archaeologists and architects from the University of L'Aquila, the ICT-CNR in L'Aquila and the crater area's Special Office for Reconstruction - is carrying out a number of parallel operations that are designed to:

- identify likely instances of pervasive cracking, which tends to affect the points at which different stratigraphic elements meet, if these are not well anchored to one another, or areas of stone or brickwork characterised by voids, whether these are filled in or not (e.g., windows, putlog holes, flues, sewer channels etc.);

- form a picture of the diachronic development of the buildings that make up the Castle complex with a view to assessing each dwelling's vulnerability to further seismic shock in relation to the modified static conditions to which it is currently subject;

- identify, describe and date historical earthquake damage using stratigraphic data and studying macro-elements within the structures. In this sense, stratigraphic analysis is fundamental in identifying and evaluating those areas that are most prone to kinematic phenomena of this sort since it highlights elements that are potentially vulnerable to the effects of seismic activity, such as areas of cracking that have not been properly restored, interfaces between layers that have not been suitably anchored, areas characterised by changes in materials and construction methods, and so 
on;

- assess the current condition of the buildings with a view to conducting subsequent vulnerability analysis and identifying the type of work that needs done on the structure. Clarifying the relationship between stratigraphy and macro-elements is a primary consideration in analysing a building because it makes it possible to attribute certain changes in the overall structure to specific destructive phenomena and subsequent repairs. As such, stratigraphic analysis allows the researcher to speculate as to how a building has responded to earthquakes that may have affected it in specific historical periods, and as to which instance of damage is related to the seismic activity with which the study is primarily concerned;

- identify, date and describe "anti-earthquake measures", meaning all procedures and methods employed to mitigate, repair or counter the effects of seismic activity, whether they are implemented retrospectively, following an earthquake, or during the building phase in anticipation of earthquakes to come.

\section{Future Scope and Potential of the Study}

Taking our lead from the analysis of this single sample area, we have deduced a working reference model of the history of the wider area that leads us to consider the building methods identified in terms of what they reveal both about the role of the various individuals involved in commissioning and implementing the construction of a building (and any other work carried out on it) in one or more periods in history, and about the economic, political and social considerations reflected in the choices they made. Looking to the future, this model could, in fact, constitute a pilot study for investigations over wider geographical areas and exemplify a genuinely multidisciplinary approach to the study of seismic risk, one that is characterised by the exchange of ideas and engagement between humanistic and scientific disciplines.

In the wider landscape of academic research into earthquakes and their implications for our built cultural heritage and the landscape - and the societies that occupy them-archaeoseismology represents a new, innovate approach. By acquiring as much information as possible about a building that is potentially at risk from seismic activity - something that the ministerial guidelines mentioned earlier identify as a fundamental requirement-we can better identify what sort of work is needed in a particular study context. As such, it is an essential process that needs to be implemented before a future earthquake robs us of the opportunity.

\section{Conclusions}

We expect the proposed research methodology and the survey process currently under way to yield a range of both quantitative and qualitative data to supplement our understanding of historical seismic activity. These data, if correctly interpreted, are of great potential utility in the context of any preliminary analysis applied prior to carrying out work directly on a particular heritage asset, and more generally in relation to our attempts to understand the history and seismology of the wider territory before beginning the process of restoration. By helping to evaluate certain elements that are key to our understanding of an area's seismic risk, specifically factors of risk, vulnerability and exposure, archaeology can serve as the linchpin of any investigation of the seismological make-up of a particular research context and the effects of past earthquakes on its historic buildings.

There are also significant social implications that push the project into the realms of public archaeology, particularly in regard to the relationship between communities and municipal authorities. Indeed, the process of analysing buildings in terms of an area's seismological history can help in raising awareness among populations who live in areas of elevated seismic risk and informing them of the actual likelihood of future seismic activity and the effects it might have on civil constructions. Ultimately, the project can also 
add to this wider population's awareness of its own history and the earthquakes that have affected the area in which it lives. As such, it can only help strengthen the cultural identity of the region.

\section{References}

[1] Ministero per i beni e le Attività Culturali, Segretariato Generale, Roma. 2010. Linee Guida per la Valutazione e Riduzione del Rischio Sismico del Patrimonio Culturale. Allineamento alle Nuove Norme Tecniche per le Costruzioni: Circolare n. 26, December 12, 2010. (in Italian)

[2] Ganz, M., and Doglioni, F. 2014. "Criteri per il Riconoscimento Dell'Origine Sismica di Danni Stratificati. Il Santuario dei SS. Vittore e Corona a Feltre come tema di Archeosismologia." Archeologia dell'Architettura XIX: 8-49. (in Italian)

[3] Galadini, F., Hinzen, K. G., and Stiros, S. 2006. "Archaeoseismology: Methodological Issues and Procedure." Journal of Seismology 10: 395-414.

[4] Noller, J. 2011. "Archaeoseismology: Shaking Out the History of Humans and Earthquakes." Earth Sciences and Archaeology, edited by Goldberg, P., Holliday, V. T., and Ferring, C. R. New York: Kluwer Academic/Plenum Publishers, 143-70.

[5] Santoro Bianchi, S. 1996. "Dalla Sismologia Storica all'Archeosismologia." OCNUS, Quaderni della Scuola di Specializzazione in Archeologia 4: 239-48. (in Italian)

[6] Stiros, S., and Jones, R. E. 1996. "Archaeoseismology." British School at Athens, Fitch Lab. Occasional Paper 7: 23-36.

[7] Bottari, C. 2006. "Ancient Constructions as Markers of Tectonic Deformation and of Strong Seismic Motions." In Proceedings of 11th FIG Symposium on Deformation Measurements, 761-5.

[8] Evans, A. J. 1928. The Palace of Minos at Knossos II. London: Macmillan.

[9] Karcz, I., and Kafri, U. 1978. "Evaluation of Supposed Archaeoseismic Damage in Israel." Journal of Archaeological Science 5: 237-53.

[10] Stiros, S. 1995. "Archaeological Evidence of Antiseismic Construction in Antiquity." Annali di Geofisica XXXVIII (November-December): 725-36.

[11] Arrighetti, A. 2015. L'Archeosismologia in Architettura. Per un Manuale. Firenze: University Press. (in Italian)

[12] Redi, F., Forgione, A., and Romiti, E. 2012. "Rilevamento dell'Edilizia Storica e Valutazione del Danno Sismico all'Aquila e Territorio Prima e dopo il 6 Aprile 2009." In Atti del VI Congresso degli Archeologi Medievisti Italiani, 763-8. (in Italian)

[13] Parenti, R., Vecchi, A., and Gilento, P. 2010. "Archeologia dell'Architettura e Rischio Sismico."
Archeologia dell'Architettura XIII: 15-28. (in Italian)

[14] Brogiolo, G. P. 2008. "Procedure di Documentazione e Processi Interpretativi dell'Edilizia Storica alla luce Delle Linee Guida per la Valutazione e Riduzione del Rischio Sismico del Patrimonio Culturale." Archeologia dell 'Architettura XIII: 9-13. (in Italian)

[15] Rideaud, A., and Levret, A. 1999. "Traces de Séismes Historiques sur le bâti Ancien en Moyenne Durance: Beaumont-de-Pertuis." In Archéosismicité et Vulnérabilité du Bâti Ancien. Actes des IV Rencontres du Groupe APS, 39-64. (in French)

[16] Fiches, J. L., Helly, B., and Levret, A. 1995. “Archéologie et Sismicité. Autour d'un Grand Monument, le Pont du Gard." In Actes de Journées d'étude, APDCA, 171. (in French)

[17] Boschi, E., Guidoboni, E., Ferrari, G., Gasperini, P., Smriglio, G., and Valensise, G. 1995. Catalogo dei Forti Terremoti in Italia dal 461 a.C. al 1980. Bologna: ING-SGA. (in Italian)

[18] Guidoboni, E., ed. 1989. I Terremoti Prima del Mille in Italia e nell'Area Mediterranea. Storia, Archeologia, Sismologia. Bologna: SGA. (in Italian)

[19] Arrighetti, A., Castelli, V., and Sessa M. 2013. "Sismicità e Cinetiche di Degrado Strutturali. Il Contributo dell'Archeologia dell'Architettura." In Atti del Convegno Internazionale di Studi "Conservazione e Valorizzazione dei siti archeologici”: 551-60. (in Italian)

[20] Lagomarsino, S., and Boato, A. 2011. "Stratigrafia e Statica." Archeologia dell'Architettura XV: 47-53. (in Italian)

[21] Brogiolo, G. P., and Faccio, P. 2010. "Stratigrafia e Prevenzione." Archeologia dell'Architettura XV: 55-63. (in Italian)

[22] Doglioni, F. 1997. Stratigrafia e Restauro. Tra Conoscenza e Conservazione dell'Architettura. Trieste: Lint Editorale Associati. (in Italian)

[23] Doglioni, F. 2008. Nel Restauro. Progetti per le Architetture del Passato. Venezia: Marsilio. (in Italian)

[24] Faccio, P. Masciangelo, L., and Zeka Lorenzi, F. 1997. "Potenzialità Applicative dell'Analisi Stratigrafica. Ricostruzione di una Possibile Storia Meccanica di un Edificio Storico." Archeologia dell'Architettura II: 53-61. (in Italian)

[25] Cagnoni, G. 1996. "La Documentazione del Degrado e del Dissesto nell'Analisi Stratigrafica degli Elevati." Archeologia dell'Architettura I: 65-8. (in Italian)

[26] D'Antonio, M. 2013. Ita Terraemotus Damna Impedire. Note Sulle Tecniche Antisismiche Storiche in Abruzzo. Pescara: Carsa Edizioni. (in Italian)

[27] Brogiolo, G. P., and Cagnana, A. 2012. Archeologia dell'Architettura, Metodi e Interpretazioni. Firenze: All'Insegna del Giglio. (in Italian). 